\title{
Toxicological

\section{Protective effects of Aloe vera extract on aluminium sulphate induced alterations in serum lipid profile of male albino rats, Rattus norvegicus}

\author{
Gajendra Mahor and Sharique A. Ali* \\ Rajeev Gandhi National Fellow UGC, New Delhi Department of Biotechnology, Saifia Science College, \\ Bhopal - 462001, India
}

\begin{abstract}
The present study suggests that treatment with Aloe vera a medicinal plant belonging to the family - Liliaceae, used in traditional Indian medicine system and its active constituent Aloin has a positive and therapeutic effect in lowering the lipid profile level in aluminium sulphate exposed rats for a period of 60 to 90 days. Lipid profile (total cholesterol, triglyceride, HDL and LDL) levels were found to significantly increased $(P<0.05)$ after treatment of $\mathrm{Al}_{2}\left(\mathrm{So}_{4}\right)_{3}$ in $\mathrm{Group}_{2}$ II compared to normal control Group I treated with normal diet. Group III and Group IV animals treated with $\mathrm{Al}_{2}\left(\mathrm{So}_{4}\right)_{3}$ and Aloe vera extract and $\mathrm{Al}_{2}\left(\mathrm{So}_{4}\right)_{3}$ and Aloin respectively, showed significant decrease in lipid profile at $(P<0.05)$. The present study also validates that $A$.vera extract and pure aloin was effective in reducing $\mathrm{Al}$ toxicity in lipid profile (Total Cholesterol, Triglyceride, HDL and LDL) of treatment in the long term 60 and 90 days of aluminium exposed rats.
\end{abstract}

\section{KEY WORDS: ALOE VERA, ALUMINIUM TOXICITY, TOTAL CHOLESTEROL, TRIGLYCERIDE, HDL AND LDL}

\section{INTRODUCTION}

Aluminium (Al) is the third most abundant metal present naturally in the Earth's crust. It is also present in soil, air, water, several eatables, and commercial products such as food storage material, cookware, and medicinal products including drugs. Exposure to humans occurs

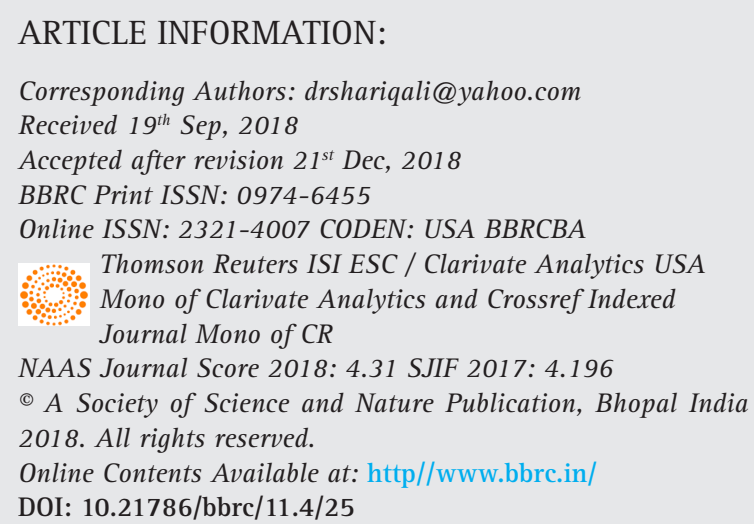

through different routes. The common routes of exposure include inhalation, oral, and skin. Exposure is more common among people working in $\mathrm{Al}$ industries. The extensive use of $\mathrm{Al}$ cookware leads to ingestion of small quantities of $\mathrm{Al}$ every day. $\mathrm{Al}$ is found to be a component of commonly used medications such as anti-ulcer drugs such as sucralfate, antacids containing $\mathrm{Al}$, hae- 
modialysis fluid, phosphate binders and vaccines. $\mathrm{Al}$ is also found in anticaking agents, preservatives, fillers, coloring agents, emulsifiers and baking powders. Such extensive use of $\mathrm{Al}$ in consumable and non consumable products will certainly lead to $\mathrm{Al}$ entry and deposition in human body, (Denise et al., 2007; Verstraeten et al., 2008; Gura, 2010; Thirunavukkarasu et al., 2013; Kalaisevi et al., 2015; Sakr et al., 2017; Konda et al., 2017; Ahmed et al., 2018).

$\mathrm{Al}$ does not have any physiological role in the body but it gets stored mainly in the blood, lungs, liver, bones, brain, spleen, kidney and muscles. It may act as a competitive inhibitor for elements such as magnesium, iron and calcium because of its atomic size and electric charge and may results in anaemia and bone damage. Al-induced neurotoxicity and changes in serum lipid profile and vitamins. High level of exposure can cause toxicity such as nephrotoxicity and hepatotoxicity. It was already been reported in patients with chronic kidney disease who were on dialysis with Al-containing dialysis fluid. Al toxicity has been associated with Alzheimer's disease, dialysis, Parkinson's dementia. It is due to oxidative stress and lipid peroxidation in tissues, Protein and DNA (Tchounwou et al., 2012; Thomford et al., 2017; Azza et al., 2017).

Lipid is an important component of human body because it is a main constituent of cell membrane, several hormones and also performs many other cellular functions (Esther et al., 2013). Lipids being insoluble in the blood so it is transported from the cells by low density and high density lipoproteins (Brown et al., 2007; Kaji et al., 2013). High density lipoproteins (HDL) tend to carry cholesterol away from arteries back to the liver (Van der Veen et al., 2009). Therefore, high serum cholesterol level can be due to hepatic dysfunction. Although several factors, such as life style, a diet rich in cholesterol, age and hypertension, have been reported to cause heart failure (Kumar et al., 2011). High levels of cholesterol, particularly LDL cholesterol, are mainly responsible for hypercholesterolemia provoked cardio toxicity (Azad et al., 2001).

Several anti-hyperlipidemic agents are currently available; however most of them have associated with various unwanted effects. Hence, people are switching towards safer alternatives, specially derived from plants with limited side effects. The World Health Organization (WHO) has given its estimation that more than $2 / 3^{\text {rd }}$ of the global population in recent times depends on alternative sources of treatment to fulfil the basic health care requirements and this most importantly embroils the usage of plant products. This means that nearby twothirds of the people globally trust on plants as a reliable way of their medication. Nowadays, vigorous research is ongoing to discover nontoxic and beneficial herbs.
Herbal Medicine or herbalism is the practice or art of employing herbs and herbal preparations in order to remain healthy and also for the treatment and improvement in prognosis of diseases. A.vera is a medicinal plant belongs to the family Liliaceae its active constituent aloin have antioxidant properties, protective against heavy metal toxicity. Its therapeutic applications include wound healing, diabetes, burns for easing intestinal, curing ulcers and arthritic swelling (Kumar et al., 2010; Sai et al., 2011; Jakkala et al., 2015; Mahor et al., 2016; Gupta et al., 2017). The aim of the present study was to investigate the protective role of A.vera on $\mathrm{Al}$ induced changes in lipid profile (cholesterol, triglyceride, HDL and LDL) of experimental rats.

\section{MATERIALS AND METHODS}

Collection and identification of plant material: The fresh leaves of A.vera (Aloe barbadensis) were collected from the Minor Forest Produce Processing and Research Centre (MFP-PARC) Van Parisar, Barkhera Pathani, Bhopal, (M.P.) India. The plant was authenticated by Dr. Zia-Ul-Hassan Head of the Department of Botany at the Saifia College of Science Peer Gate, Bhopal, (M.P.) India and the voucher specimen (403/Saifia/Bot/16) has been deposited at the Herbarium of the Saifia Science College, Peer Gate, Bhopal, (M.P.) India.

Preparation of extracts: After collection and weighing, fresh leaves of Aloe vera were washed with distilled water to remove dirt and dried under shade separately. The extraction of $A$. vera leaves was done according to the method (Kumar \&t Muthuselvam, 2009). Slight modification, Skin of the leaves were pealed and the gel inside was used for extraction. $100 \mathrm{gm}$ of the gel was added to $250 \mathrm{ml}$ of ethanol and extracted using the Soxhlet assembly. Later on, the solvent of the extracted material was removed at low temperature in a rotary vacuum evaporator and the resulting dried extract was lyophilized in a freeze dryer.

Drugs and chemicals: In this study, Al-sulphate $\left(\mathrm{Al}_{2} \mathrm{So}_{4}\right)_{3}$ was purchased from Aldrich chemical Company (St. Lousis mo, USA) and Standard Aloin (C21H2209) was obtained from Sigma. The diagnostic kits required for enzymatic assays were purchased from Span Diagnostics. All other chemicals used in the experiment were of analytical grade. The dose of $\mathrm{Al}$-sulphate $\left(\mathrm{Al}_{2} \mathrm{So}_{4}\right)_{3}$ was $98 \mathrm{mg}\left(\mathrm{Al}_{2} \mathrm{So}_{4}\right)_{3} / \mathrm{L}(1 / 25 \mathrm{LD} 50)$. The dose of A.vera extract and Aloin were $100 \mathrm{mg} / \mathrm{kg}$ BW. These doses were selected based on basis of pilot experiments.

Maintenance of animals and approval of protocol: Healthy adult male albino rats (Rattus norvegicus) weighing 120-150g were used for the present investiga- 
tion. They were housed in a clean polypropylene cage and maintained in an air-conditioned experimental room at 12-hour light: dark cycles. The animals were acclimatized to laboratory condition for one week prior to experiment. Standard pellets were used as a basal diet during the experimental period. The control and experimental animals were provided with purified drinking water ad libitum. The animals were maintained in accordance with the "CPCSEA guidelines for laboratory animal facility" (Committee for the Purpose of Control and Supervision on Experiments on Animals) and the approval number is CPCSEA Registration number SSC/06-06-22/CPCSEA, dated 26/10/2006. Before starting the experiment the animals were carefully marked on different parts of their body, which was later used as identification mark for a particular animal, so that the response of a particular mouse prior to and after the administration could be noted separately.

Acute oral toxicity studies: A.vera extract at the dose range of $100-2500 \mathrm{mg} / \mathrm{kg}$ body weight were administered by oral gavage method on different group of mice comprised of 6 rats in each group. Animals were kept under close observation for 4 hours after administering the fraction for behaviour, neurological, and autonomic profile and then observed for any change in the general behaviour and physical activities; mortality was recorded within 72 hours. Acute toxicity was determined according to the method (Lorke, 1983).

Induction of Toxicity/experimental design: A total of 24 male (2 months old) Albino rats (Rattus norvegicus) weighing 120-150g were used for the present investigation. The animals were divided into four groups (6 rats/ group): Group I:-was kept as control without giving any treatment. Compared to adult controls, Group II: - animals in this group were given $17 \pm 6 \mathrm{ml}$ of water supplemented with Al-sulphate to consume, corresponding to $98 \mathrm{mg}$ of Al per day (Laxman et al., 2016) for 60 and 90 days. Group III: - This group animals were fed with normal diet and received aluminium sulphate $(98 \mathrm{mg} /$ $\mathrm{kg}$ body weight) and Aloe vera extract (100 mg/kg body weight) for 60 and 90 days. Group IV: - This group animals were fed with normal diet and received aluminium sulphate (98 mg/kg body weight) and Aloin (100 mg/kg body weight) for 60 and 90 days.

Animal Grouping and Treatment Schedule: Four groups of rats, six rats in each, received the following treatment schedule: Group I rats received normal diet and water ad libitum, as control group. Group-II rats administered twice with Aluminium sulphate $(98 \mathrm{mg} /$ $\mathrm{kg} /$ day) dissolved in $(1 \mathrm{ml} / \mathrm{kg}$ b.wt) water were injected dose orally for 60 and 90 days. Group III, will be administered with Aluminium sulphate $(98 \mathrm{mg} / \mathrm{kg} / \mathrm{b}$.w.) with
Aloe vera extract (100 mg/kg/b.w.) dose orally for 60 and 90 days and last Group-IV rats were administrated Aluminium sulphate $(98 \mathrm{mg} / \mathrm{kg} / \mathrm{b} . w$.$) with Aloin (100 mg/$ $\mathrm{kg} / \mathrm{b} . \mathrm{w}$.) dose orally for 60 and 90 days.

Collection of Blood Sample and Estimation of Serum Lipid profile Investigations: Blood samples were collected by orbital sinus puncture method (Hui et al., 2007). Serum was separated by following procedure. Blood samples were withdrawn from orbital sinus using non heparinised capillary tubes, collected in dried centrifuge tubes and allowed to clot. Serum was separated from the clot by centrifuged at $3000 \mathrm{rpm}$ for $15 \mathrm{~min}$. at room temperature. Serum was collected carefully and kept at $-20^{\circ} \mathrm{C}$ until analysis of Total cholesterol, High Density Lipoprotein (HDL) cholesterol and triglycerides by using kits supplied by Span Diagnostic Ltd. Plasma concentrations of total cholesterol, triglycerides, HDL \& LDL fractions were measured by using standard methods with commercially available kits. LDL cholesterol was calculated with the Friedewald formula as follows: LDL cholesterol $=$ total cholesterol - HDL cholesterol - (triglycerides/5) (Friedewald et al., 1972).

STATISTICAL ANALYSIS OF DATA: All parameters were presented as mean \pm SEM. One-way analysis of variance followed by Bonferroni multiple comparisons using a computer-based fitting program (Prism, Graph $\mathrm{Pad}$ ) were performed. Differences were considered to be statistically significant when $P<0.05$.

\section{RESULTS}

It was obsevered that all four groups of rats received the following treatment schedule: shows the significant change in all parameters discussed here. After 60 days (Group II) showed a significant $(P<0.05)$ increase in the level TC, TG, HDL and LDL due to Al toxicity compared to group I. whereas significant $(P<0.05)$ decrease in TC, TG, HDL and LDL level was reported in group III and group IV (Table:1), (Fig: 1).Experimental results shows. After 60 days group III and group IV showed a significant $(P<0.05)$ decrease in the level TC, TG, HDL and LDL which is induced due to Al toxicity group II compared to group I (Table: I), (Fig: I).

After 90 day study it was observed that $\mathrm{Al}$ toxicity enhances compared to 60 or 90 days. It means $\mathrm{Al}$ on long term exposure induces toxicity in group II whereas A.vera extract and aloin was also effective in reducing toxicity in various parameters studied after 90 days. After 90 days group III and group IV showed a significant $(P<0.05)$ decrease in the level of TC, TG, HDL and LDL which is induced due to Al toxicity group II nearest about to group I. (Table:II) and (Fig: II), 




FIGURE 1. Graph showing variation in different levels of Total Cholesterol: Triglycerides, HDL and LDL against Aluminium sulphate $(98 \mathrm{mg} / \mathrm{kg} / \mathrm{bw})$ induced toxicity after 60 days.

Table 1. Effects of orally administrated A. vera extract and aloin on Total Cholesterol, Triglycerides, High density lipoproteins, Low density lipoprotein intoxicated with Aluminium sulphate after 60 days.

\begin{tabular}{l|l|l|l|l|l|}
\hline Group & Treatment & $\begin{array}{l}\text { Total Cholesterol } \\
(\mathrm{mg} / \mathrm{dl})\end{array}$ & $\begin{array}{l}\text { Triglycerides } \\
(\mathrm{mg} / \mathrm{dl})\end{array}$ & HDL (mg/dl) & LDL (mg/dl) \\
\hline I & Normal Control & $99.33 \pm 5.391$ & $93.33 \pm 5.755$ & $38.17 \pm 5.115$ & $31.50 \pm 1.871$ \\
\hline II & Al2(So4)3 $(98 \mathrm{mg} / \mathrm{kg})$ & $129.83 \pm 2.316$ & $139.83 \pm 3.312$ & $17.83 \pm 2.317$ & $50.67 \pm 4.179$ \\
\hline III & $\begin{array}{l}\text { Al2(So4)3 }(98 \mathrm{mg} / \mathrm{kg})+ \\
\text { A.vera extract }(100 \mathrm{gm} / \mathrm{kg})\end{array}$ & $95.16 \pm 2.136^{*}$ & $95.17 \pm 4.446^{*}$ & $33.17 \pm 5.037^{*}$ & $27.50 \pm 4.848^{*}$ \\
\hline IV & $\begin{array}{l}\text { Al2(So4)3 }(98 \mathrm{mg} / \mathrm{kg})+ \\
\text { Aloin (100gm/ } / \mathrm{kg})\end{array}$ & $95.33 \pm 3.444^{* * *}$ & $87.83 \pm 4.401^{* *}$ & $37.33 \pm 5.715^{* * *}$ & $25.17 \pm 2.317^{* * *}$ \\
\hline
\end{tabular}

${ }^{*} \mathrm{C}{ }^{* *}=$ indicates significant values, significantly different at $\mathrm{P} \leq 0.05$.

Table 2. Effects of orally administrated A. vera extract and aloin on Total Cholesterol, Triglycerides, High density lipoproteins, Low density lipoprotein intoxicated with Aluminium sulphate after 90 days.

\begin{tabular}{l|l|l|l|l|l|}
\hline Group & Treatment & $\begin{array}{l}\text { Total Cholesterol } \\
(\mathrm{mg} / \mathrm{dl})\end{array}$ & $\begin{array}{l}\text { Triglycerides } \\
(\mathrm{mg} / \mathrm{dl})\end{array}$ & HDL $(\mathrm{mg}$ dl) & LDL (mg/dl) \\
\hline I & Normal Control & $101.83 \pm 4.622$ & $94.67 \pm 5.785$ & $40.00 \pm 3.950$ & $33.17 \pm 2.927$ \\
\hline II & Al2(So4)3 $(98 \mathrm{mg} / \mathrm{kg})$ & $133.17 \pm 4.070$ & $141.17 \pm 4.834$ & $15.67 \pm 1.633$ & $53.67 \pm 4.633$ \\
\hline III & $\begin{array}{l}\text { Al2(So4)3 }(98 \mathrm{mg} / \mathrm{kg})+ \\
\text { A.Vera extract }(100 \mathrm{gm} / \mathrm{kg})\end{array}$ & $92.83 \pm 3.189^{*}$ & $92.50 \pm 5.925^{*}$ & $35.50 \pm 3.507 *$ & $29.50 \pm 4.593^{*}$ \\
\hline IV & $\begin{array}{l}\text { Al2(So4)3 }(98 \mathrm{mg} / \mathrm{kg})+\text { Aloin } \\
(100 g m / \mathrm{kg})\end{array}$ & $92.67 \pm 8.238^{* *}$ & $85.50 \pm 9.731 * *$ & $38.67 \pm 4.885 * *$ & $23.67 \pm 3.983^{* * *}$ \\
\hline * $\mathrm{Ct}^{* * *}=$ indicates significant values, significantly different at P $\leq 0.05$.
\end{tabular}




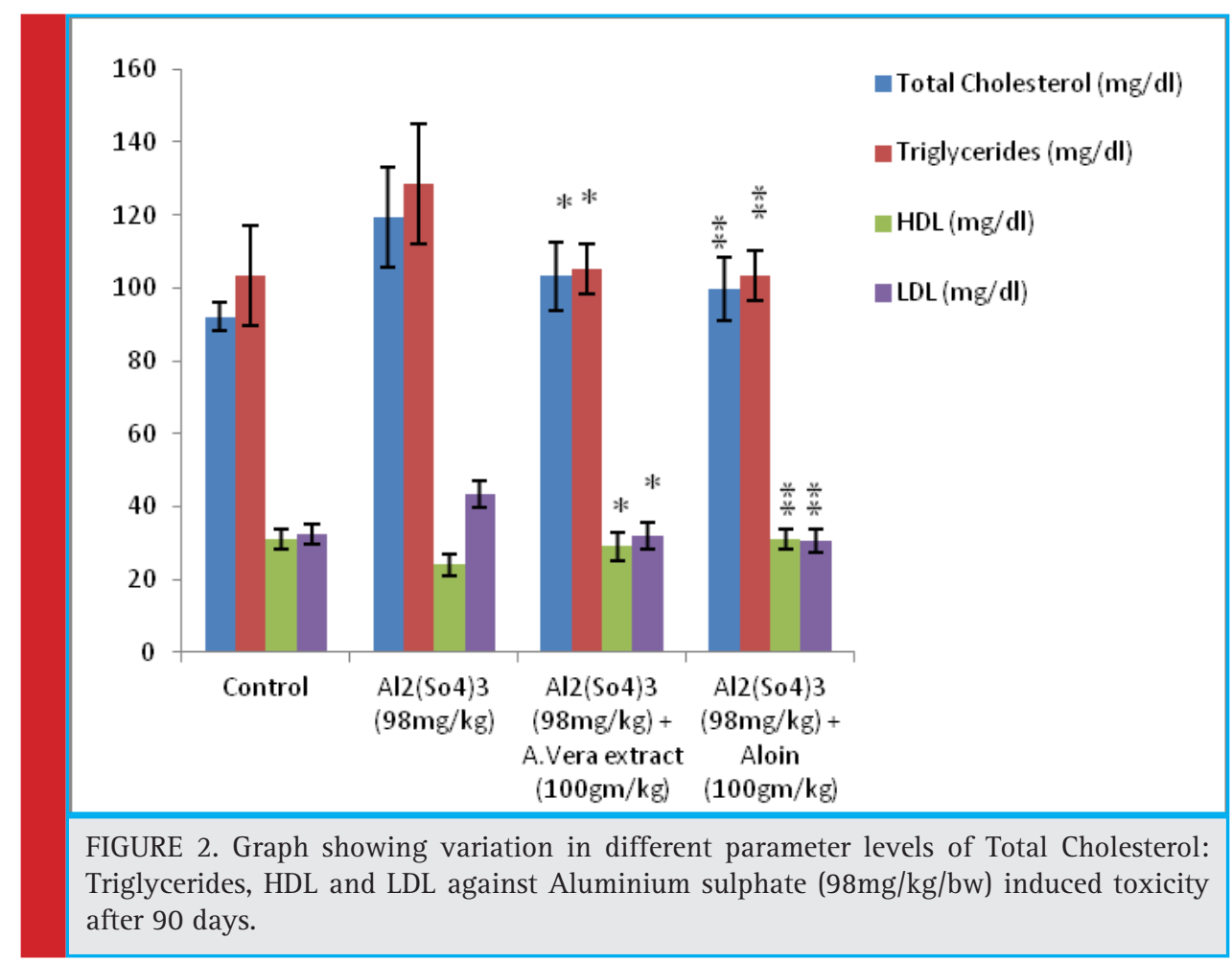

\section{DISCUSSION}

The hypertriglyceridemia and lipid oxidation were main features of this altered metabolism. Hyperlipidemia is a condition where there is an elevation of the serum levels of total cholesterol (TC) and triglycerides (TG) due to the lipid metabolism alteration, with an increase in the liver lipogenesis and lipolysis in the adipocytes. Low-density lipoprotein (LDL) is the compound containing both lipid and protein, which transport cholesterol to tissues other than the liver. High-density lipoprotein (HDL) is the compound containing both lipid and protein, which transport cholesterol to the liver for excretion in the bile. (Kalaiselvi et al., 2015; Gouda et al., 2018).

Aluminium (Al) is toxic to humans and animals. Its toxicity results to generation of reactive oxygen species in lipids which leads to oxidative damage of biomolecules in an organism. The present study investigated the effects of Al-sulphate in toxicity induction and beneficial effect of A.vera, aloin against the induced toxicity in rats. The findings of this study were that $\mathrm{Al}$ perturbed the metabolism of lipids (cholesterol, triglyceride, LDL and HDL) in rat. It may up-/down-regulation the levels of these lipids due to up- or down-regulated of enzyme. These perturbations were presented in the plasma as hypertriglyceridemia, hypercholesterolemia and hypophospholipidemia. the increase in plasma cholesterol as a result of ingestion of $\mathrm{Al}$. Due to $\mathrm{Al}$ ingestion caused a preferential activation of receptor sites on the cells which favoured the synthesis of cholesterol in these organs by up-regulating hydroxymethylglutaryl coenzyme A reductase (a rate-limiting enzyme in cholesterol synthesis pathway) since virtually all cells can synthesize cholesterol or $\mathrm{Al}$ changes the integrity of the cell membrane thereby causing a constipation of cholesterol in the organs by modification of the composition, structure and stability of the cell membranes. The liver has been shown to be one of the target organs of $\mathrm{Al}$ toxicity- induced injury, liver damage is likely to cause some membrane lipids to be released into circulation; metabolism with oxidative stress and lipid peroxidation and reactive oxygen species as hydroxyl and superoxide radicals in liver alter the lipid level in serum (Kolomiytseva, 2011; Ugbaja et al., 2015; Younes et al., 2018).

$\mathrm{Al}$ causes toxic effect on biochemical parameters i.e. Cholesterol, Triglycerides It shows an increasing trend because prolonged metallic stress in the experimental animals makes adaptation difficult and creates weakness, anemia. In the field of environmental bio monitoring these parameters have been effectively used as potential biomarkers of $\mathrm{Al}$ toxicity in animals and human. This present study was carried out to investigate the effect of A.vera, a well-known medicinal plant with antioxidant properties, on Al-induced alterations in lipid metabolism. In comparison to controls, rats with $\mathrm{Al}$ toxicity displayed higher cholesterol, triglyceride, HDL and LDL concentrations in serum (Joshi et al., 2013). 
A.vera extract has a wide range of therapeutic applications. A.vera gel contains anthroquinones (aloin, aloeemodin) which may have a variety of properties of antioxidant agent, including the protective role for heavy metal toxicity. Previous studies have also shown that as an antioxidant, plant extracts may improve the prooxidant effects of Al (Nada et al., 2013; Jakkala et al., 2016; Mahor et al., 2016).

In this study, the A.vera extract proved to be quite effective in lowering the lipid profile (total cholesterol, triglycerides, HDL and LDL) $\mathrm{Al}$ toxicity. $\mathrm{Al}$ in the blood was significantly reduced due to administration of the A.vera extract since it possesses chelating properties. Administration of the A.vera extract for 60 and 90 days lead to decreases in cholesterol, triglycerides, HDL and LDL levels in the Al-sulphate exposed animals. This implies an exacerbating effect of A.vera on Al toxicity.

\section{CONCLUSION}

The present study also validates that A.vera extract and aloin was effective in reducing $\mathrm{Al}$ toxicity in lipid profile (Total Cholesterol, Triglyceride, HDL and LDL) of treatment 60 and 90 days.

\section{CONFLICTS OF INTEREST}

The authors have no conflict of interest to declare.

\section{ACKNOWLEDGEMENT}

GM is thankful to UGC New Delhi for awarding RGNF, Vide File No.2014-15-SC-MAD-67686/ 2014.

\section{REFERENCES}

Ahmed S. Gouda, Nagla A. El-Nabarawy, Samah F. Ibrahim (2018). Moringa oleifera extract (Lam) attenuates Aluminium phosphide-induced acute cardiac toxicity in rats. Toxicology Repots.5:209-212.

Azad A., Lall SB, Mittra S. (2001). Effect of N-acetylcysteine and L-NAME on aluminium phosphide induced cardiovascular toxicity in rats. Acta Pharmacologica Sinica. 22:298-304.

Azza A. Ali, Doaa M, Latif A, Gad AM. Elnahas YM, Elfotuh KA. (2017). Nephrotoxicity and Hepatotoxicity Induced by Chronic Aluminium Exposure in Rats: Impact of Nutrients Combination versus Social Isolation and Protein Malnutrition. International Journal of Environment and Ecological Engineering. 11(1):58649-58669.

Brown WV. (2007). High-density lipoprotein and transport of cholesterol and triglyceride in blood. Journal of Clinical Lipidology. 1:7-19.

Denise B, Denise C, Bertagnolli et al., (2007). Drugs as a hidden source of aluminium for chronic renal patients. Nephrology Dial Transplant. 22:605-611.
Esther 0, Abam, Funmilola Y, Oladipo, Violette N, Atasie, Abimbola A. (2013). Effect of Walnut (Tertracarpidium conophorum)-oil on Cadmium-Induced Alterations in Lipid Metabolism in Male Albino Rats. Food and Public Health. 3(4): 169-175.

Friedewald WT, Levy RI, Fredrickson DS. (1972). Estimation of the concentration of low-density lipoprotein cholesterol in plasma, without use of the preparative ultracentrifuge. Clinical Chemist.18:499-502.

Gouda SA, Nabarawy AN, Ibrahim FS. (2018). Moringa oleifera extract (Lam) attenuates Aluminium phosphide-induced acute cardiac toxicity in rats. Toxicology Reports. 5:209-212.

Gupta A and Rawat S. (2017). Clinical importance of Aloe vera: Review. Research Journal of Topical and Cosmetic Sciences. 8(1):0976-2981.

Gura KM. (2010). Aluminium contamination in products used in parenteral nutrition: has anything changed. Nutrition. 26(6): 585-594.

Hui Y, Huang NH, Ebbert L, Bina H, Chiang A. (2007). Pharmacokinetic comparison of tail-bleeding with cannula-or retro-orbital bleeding techniques in rats using six marketed drugs. Journal of Pharmacological and Toxicological Methods. 56:256-264.

Jakkala LK and Ali A. (2016). Aloe vera protects the Aluminium induced changes in testicular enzymes activity of Albino rats, Rattus Norvegicus. World Journal of Pharmacy and Pharmaceutical Sciences. 5(5):1091-1104.

Jakkala LK and Ali SA. (2015). Aloe vera Protects the Aluminium induced degenerative changes in liver and kidney of Albino Rats, Rattus norvegicus. Journal of Global Biosciences. 4(8):3158-3164.

Joshi DK, Choudhary M, Tripathi S, Pal A, Mahdi AA. (2013). Docosahexaenoic Acid Reverses Aluminium Induced Alteration in Vitamins and Lipid Profile in Rat Serum. International Journal of Pharma and BioScience. 4(1):485-493.

Kaji H. (2013). High-Density Lipoproteins and the Immune System. Journal of Lipids. (684903):1-8.

Kalaiselvi A, Aadhinath RG, Ramalingam V. (2015). Ameliorating effect of ginger extract (Zingiber officinale Roscoe) on liver marker enzymes, lipid profile in aluminium chloride induced male rats. International Journal of Pharmaceutical Science and Drug Research.7:52-8.

Kalaisevi A, Aadhinath Reddy G, Ramalingam V. (2015). Ameliorating effect of ginger (Zingiber officinale Roscoe) extract on liver marker enzymes, lipid profile in aluminium chloride induced male rats. International Journal of Pharmacological Science Drug and Resepters 2015; 7: 52-8.

Kolomiytseva IK. (2011). Lipids in mammalian hibernation and artificial hypobiosis. Biochemistry (Moscow). 76 (12):12911299.

Konda VR, Eerike M, Chary R P,Arunachalam R, Yeddula VR, Meti V, Devi T S. (2017). Effect of aluminium chloride on blood glucose level and lipid profile in normal, diabetic and treated diabetic rats.49 (5):357-365. 
Krewski D, Yokel RA, Nieboer E, Borchelt D, Cohen J. (2007). Human health risk assessment for aluminium, aluminium oxide, and aluminium hydroxide. Journal of Toxicology and Environmental Health. 10(1):1-269.

Kumar A and Muthuselvan S. (2009). Analysis of phytochemical constituents and antimicrobial activities of Aloe vera $\mathrm{L}$. against clinical pathogens. World Journal of Agricultural Sciences. 5(5):572-576.

Kumar A, Prakash A, Dogra S. (2011). Neuroprotective effect of carvedilol against aluminium induced toxicity: possible behavioural and biochemical alteration in rats. Pharmacological Reports. 63(4):915-23.

Kumar K D, Bhowmik L, Chiranjib and Biswajit B. (2010). Aloe vera: A Potential Herb and its Medicinal Importance. Journal of Chemistry and Pharmaceutical Research. 2:21-29.

Lorke D. (1983). A new approach to practical acute toxicity testing. Archives Toxicology. 54:275-287.

Mahor G and Ali SA. (2016) Recent update on the medicinal properties and use of Aloe vera in the treatment of various ailments. Bioscience Biotechnology Research Communication. 9(2):273-288.

Nada AS, Hawas AM, Elmageed ZYA, Amin NE. (2013). Protective value of Aloe vera extract against $\Upsilon$-irradiation-induced some biochemical disorders in rats. Journal of Radiation Research and Applied Sciences. 6(2):31-32.

Rajput MA, Khan RA, Assad T. (2017). Evaluation of the AntiHyperlipidemic Activity of Nelumbo nucifera fruit in Rabbits fed with High Cholesterol Diet. Pharmacology \& Pharmacy. 8:205-213.

Sai K, Radha K and Gowrinath R. (2011). Anti-ulcer effect of Aloe vera in non-steroidal anti-inflammatory drug induced peptic ulcers in rats. African Journal of Pharmacy and Pharmacology. 5:1867-1871.

Sakr SA, Mesady FA, Hashem AM. (2017). Aluminium induced Reproductive Dysfunction in Male Rats: The Ameliorative Effect of Saffron Extract. IJPPR.Human. 10(3):180-195.

Tchounwou PB, Yedjou CG, Patlolla AK, Sutton DJ. (2012). Heavy Metals Toxicity and The Environment. NIH Public Access. 101:133-164.

Thirunavukkarasu SV, Jayanthi M, Raja SV. (2013). Effect of Manasamitra Vatakam Against Aluminium Induced Learning and Memory Impairment of Apoptosis in Rat's Hippocampus and Cortex. Journal of Drug Metabolism \& Toxicology. 4 (4):1-11.

Thomford NE, Dzobo K, Chopera D, Wonkam A, Skelton M, Blackhurst D, Chirikure S and Dandara C. (2015). Pharmacogenomics Implications of Using Herbal Medicinal Plants on African Populations in Health Transition. Pharmaceuticals. 8(3):637-663.

Ugbaja RN, Olaniyan TO, Afolabi OK, Dosumu OA, Akinloye DI, Mufuatu AO, John OP. (2015). Vitamins C and E attenuate lipid dystrophy in tissues of rats administered aluminium. African Journals online. 2:98-105.

Van der Veen J, van Dijk T, Vrins C, van Meer H, Havinga R, Bijsterveld K, Tietge U, Groen A, Kuipers F. (2009). Activation or the liver $\mathrm{X}$ receptor stimulates trans-intestinal of plasma cholesterol. Journal of Biological Chemistry 284:19211-19219.

Verstraeten SV, Aimo L, Oteiza PI. (2008). Aluminium and lead: Molecular mechanisms of brain toxicity. Archives Toxicology. 82:789-802.

Younes M, Aggett P, Aguilar F, Crebelli R. (2018). Safety of hydroxyanthracene derivatives for use in food. European Food Safety Authority Journal. 16(1):1831-4732. 